Article

\title{
Improvement of Organosolv Fractionation Performance for Rice Husk through a Low Acid-Catalyzation
}

\author{
Tae Hoon Kim ${ }^{1,2}$, Hyun Jin Ryu ${ }^{1}$ and Kyeong Keun Oh ${ }^{1,3, *(D)}$ \\ 1 R\&D Center, SugarEn Co., Ltd., Yongin, Gyeonggi-do 16890, Korea; thkim@sugaren.co.kr (T.H.K.); \\ hjryu@sugaren.co.kr (H.J.R.) \\ 2 Department of Materials Science and Chemical Engineering, Hanyang University, Ansan, \\ Gyeonggi-do 15588, Korea \\ 3 Department of Chemical Engineering, Dankook University, Youngin, Gyeonggi-do 16890, Korea \\ * Correspondence: kkoh@dankook.ac.kr; Tel.: +82-31-8005-3548
}

Received: 18 April 2019; Accepted: 9 May 2019; Published: 11 May 2019

\begin{abstract}
For the effective utilization of rice husk, organosolv fractionation was investigated to separate three main components (glucan, xylose, and lignin) with low acid concentration. Reaction temperatures of $170-190{ }^{\circ} \mathrm{C}$, ethanol concentrations of $50 \%-70 \%(v / v)$, and sulfuric acid concentrations of $0 \%-0.7 \%(w / v)$ were investigated, with the reaction time and liquid-to-solid ratio kept constant at $60 \mathrm{~min}$ and 10, respectively. The fractionation conditions for the efficient separation into the three components of rice husk were determined to be $180{ }^{\circ} \mathrm{C}, 60 \%(v / v)$ of ethanol, and $0.25 \%(w / v)$ of sulfuric acid. Under these fractionation conditions, $86.8 \%$ of the xylan and $77.5 \%$ of the lignin were removed from the rice husk, and xylose and lignin were obtained from the liquid in $67.6 \%$ and $49.8 \%$ yields, respectively. The glucan digestibility of the fractionated rice husk was $85.2 \%$ with an enzyme loading of 15 FPU (filter paper unit) of cellulase per g-glucan.
\end{abstract}

Keywords: biomass; xylan; lignin; cellulose; pretreatment

\section{Introduction}

World rice production is 685 million tons per year, and 137 million tons of rice husk (RH) is generated [1]. Despite the enormous amount of $\mathrm{RH}$, most of it is burned or buried in the ground because of lax environmental standards and technological limitations [2]. However, researchers have been attempting to develop efficient uses for RH. Because of its high ash content, $\mathrm{RH}$ has been studied in fields such as absorbents, coatings, pigments, the cement industry, insulators, rubber, and electronics [3]. However, these studies have focused only on the ash content of RH, which cannot be considered an efficient use. The composition of RH differs by location but typically includes $49.5 \%$ to $64.2 \%$ carbohydrates, including cellulose and hemicellulose, and $13.5 \%$ to $40.2 \%$ lignin [4]. In general, carbohydrates and lignin are sources of high-value-added materials in the biorefinery field. For example, pure cellulose can be converted into fibers or energy and hemicellulose can be converted into high-value-added materials such as furfural, succinic acid, and xylooligosaccharide [5]. Lignin can be used as phenolic platform chemicals such as catechols, cresols, or hydrocarbon precursors [6]. Therefore, the fractionation of lignocellulosic biomass into major components such as cellulose, hemicellulose, and lignin is an effective method to use RH [5].

Different catalysts, including acids, alkalis, organic solvents, and ionic liquids, have been used to separate the major components of lignocellulosic biomass [7]. Among these chemicals, organic solvents offer numerous advantages. Organic solvent (organosolv) fractionation can separate RH into three major components in a single process and therefore assist downstream processing, e.g., enzymatic 
hydrolysis [8]. When ethanol (EtOH) is used as an organic solvent, it can dissolve hemicellulose and lignin in the liquid hydrolyzate while leaving a high content of cellulose in the residual solid. The removal of hemicellulose and lignin from biomass improves the enzymatic digestibility of cellulose by increasing enzyme accessibility [9]. The lignin extracted into the liquid can be easily precipitated by exploiting the difference in EtOH solubility, and high-quality, high-purity lignin is precipitated [10]. Additional advantages of organosolv-precipitated lignin include a low molecular weight, uniform molecular weight distribution, hydrophobicity, and a low glass transition temperature, which makes the precipitated lignin easy to use in various applications, as previously mentioned [11]. Furthermore, $\mathrm{EtOH}$ can be easily recovered and recycled, which is economically advantageous [12]. Although EtOH is known to exhibit high solubilization of lignin, it is generally used in conjunction with an added acid catalyst. The use of an acid catalyst not only leads to a mild reaction but also decomposes the carbohydrate-lignin complex more easily than when an acid catalyst is not used $[9,13]$. Therefore, the use of an appropriate acid catalyst can improve the efficiency of the fractionation process.

The purpose of this study is to effectively extract xylose and lignin from $\mathrm{RH}$ and to improve the enzymatic digestibility of fractionated solids. The EtOH organosolv process was evaluated at various independent variables (reaction temperatures, EtOH concentrations, and sulfuric acid (SA) concentrations). The effects of independent variables were determined in order to selectively extract the desired component in one stage process. In addition, the chemical characteristics of acid-free and acid-catalyzed organosolv precipitated lignin were compared.

\section{Results and Discussion}

\subsection{Organosolv Fractionation of $R H$}

\subsubsection{Organosolv Fractionation with Reaction Temperature and EtOH Concentration}

Figure 1 presents the compositions of fractionated solid after organosolv fractionation (acid-free) under various reaction conditions. The effects of different reaction temperatures $\left(170-190^{\circ} \mathrm{C}\right)$ and $\mathrm{EtOH}$ concentrations $(50 \%-70 \%)$ were investigated. As shown in Figure 1, the glucan and xylan contents in the fractionated solid were better retained at high $\mathrm{EtOH}$ concentrations $(70 \%)$ than at low $\mathrm{EtOH}$ concentration $(50 \%)$ at all of the investigated reaction temperatures $\left(170-190^{\circ} \mathrm{C}\right)$. This phenomenon is attributed to the hydrolysis reaction of water at different $\mathrm{EtOH}$-water ratios. That is, a low EtOH concentration means a high concentration of hydronium ions, which would increase the reaction severity [14,15]. The $\mathrm{pH}$ at initial $\mathrm{EtOH}$ concentrations of $50 \%, 60 \%$, and $70 \%$ were $6.24,6.25$, and 6.25 , respectively; however, after reaction $\left(170{ }^{\circ} \mathrm{C}, 60 \mathrm{~min}\right.$, liquid-to-solid (L/S) ratio of 10), the $\mathrm{pH}$ levels of $50 \%, 60 \%$, and $70 \% \mathrm{EtOH}$ solutions were $3.32,4.12$, and 4.89 , respectively. These results are consistent with the results of the liquid hydrolyzate analysis shown in Figure 2. As the EtOH concentration $(50 \%-70 \%)$ and reaction temperature $\left(170-190{ }^{\circ} \mathrm{C}\right)$ were increased, smaller amounts of sugars (glucose and xylose) and byproducts (formic acid, acetic acid, levulinic acid, 5-HMF, and furfural) were released in the liquid hydrolyzate. As byproducts (except for acetic acid) are produced by the decomposition of cellulose and hemicellulose, they are generally used as an indicator of reaction severity [16]. In particular, the 5-HMF was generated under the most severe reaction conditions $\left(190{ }^{\circ} \mathrm{C}, 50 \%\right)$ via hexose decomposition. Under these conditions $\left(190{ }^{\circ} \mathrm{C}, 50 \%\right)$, the lignin extraction yield was only $46.0 \%$; thus, large amounts of lignin remained in the solids. 


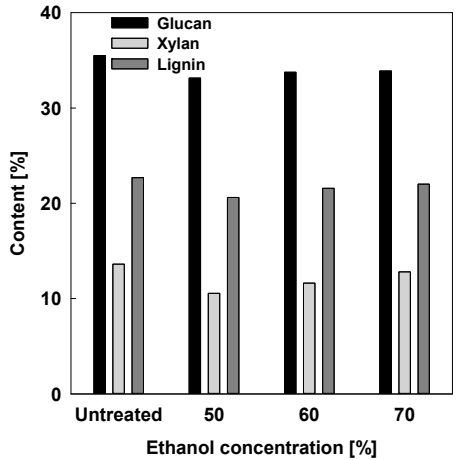

(a)

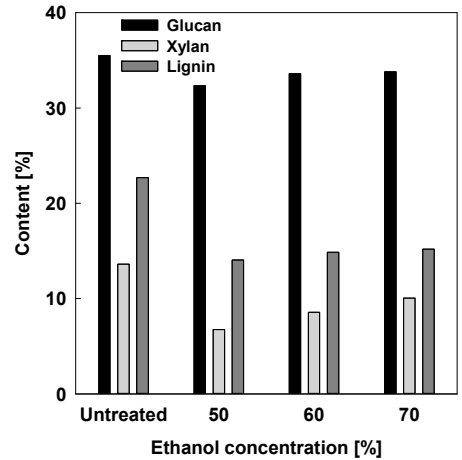

(b)

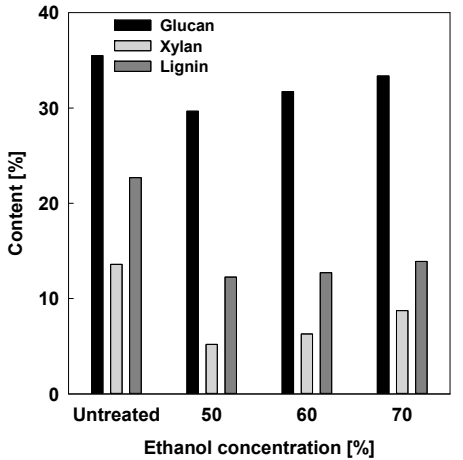

(c)

Figure 1. Effects of reaction temperature and $\mathrm{EtOH}$ concentration on the chemical compositions of the raw and fractionated solids of rice husk: (a) $170{ }^{\circ} \mathrm{C}$, (b) $180{ }^{\circ} \mathrm{C}$, and (c) $190^{\circ} \mathrm{C}$. Note: reaction conditions: $170-190{ }^{\circ} \mathrm{C}, 50 \%-70 \%$ EtOH concentration.

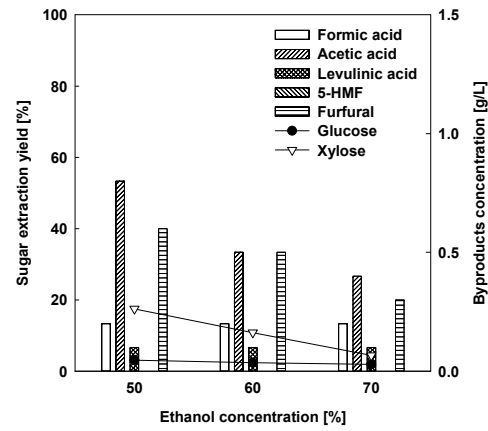

(a)

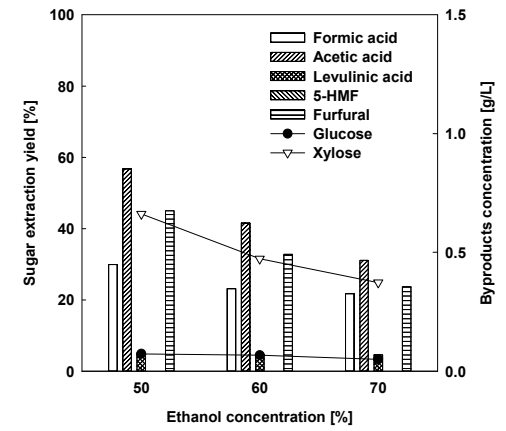

(b)

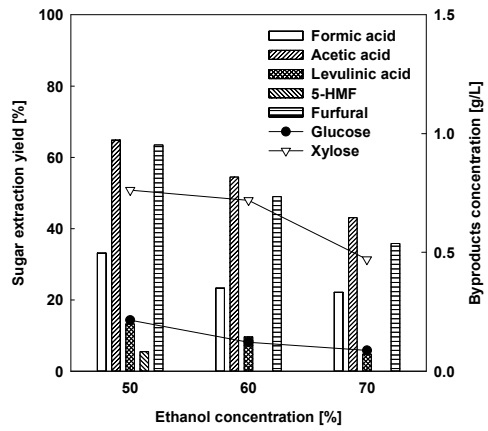

(c)

Figure 2. Effects of reaction temperature and $\mathrm{EtOH}$ concentration on the sugar extraction yield and byproducts concentration of liquid hydrolyzate: (a) $170{ }^{\circ} \mathrm{C}$, (b) $180^{\circ} \mathrm{C}$, and (c) $190^{\circ} \mathrm{C}$. Note: reaction conditions: $170-190{ }^{\circ} \mathrm{C}, 50 \%-70 \%$ EtOH concentration.

The SA was added as an acid catalyst to improve the organosolv fractionation performance. Figure 3 presents the effects of reaction temperature $\left(180^{\circ} \mathrm{C}, 190^{\circ} \mathrm{C}\right)$ and EtOH concentration $(50 \%-70 \%)$ on the chemical composition of the fractionated solid. As shown in Figure 3, the xylan content decreased under all of the investigated reaction conditions. In particular, xylan was not detected under the conditions of $190{ }^{\circ} \mathrm{C}$ and $50 \%$ or $60 \%$ EtOH concentration. However, as shown in Figure 4, xylose extracted from the RH was not present in the liquid hydrolyzate. The formation of furfural indicates decomposition of the pentose sugar (xylose), which in turn indicates an increase in the severity of the reaction conditions. As shown in Figure 4, the xylose extraction yield of liquid hydrolyzate was greater at $180^{\circ} \mathrm{C}$ than at $190^{\circ} \mathrm{C}$, which means that xylose was decomposed into furfural because of the severe conditions $\left(190^{\circ} \mathrm{C}\right)$. However, as shown in Figure 3, the glucan content $(88.4 \%-90.3 \%)$ was well preserved in the fractionated $\mathrm{RH}$ at $180{ }^{\circ} \mathrm{C}$ but was somewhat lower $(76.1 \%-77.4 \%)$ at $190{ }^{\circ} \mathrm{C}$. As previously mentioned, glucose was considered to be decomposed into byproducts such as formic acid, levulinic acid, and 5-HMF because of the severe reaction conditions at $190{ }^{\circ} \mathrm{C}$ (Figure 4). 


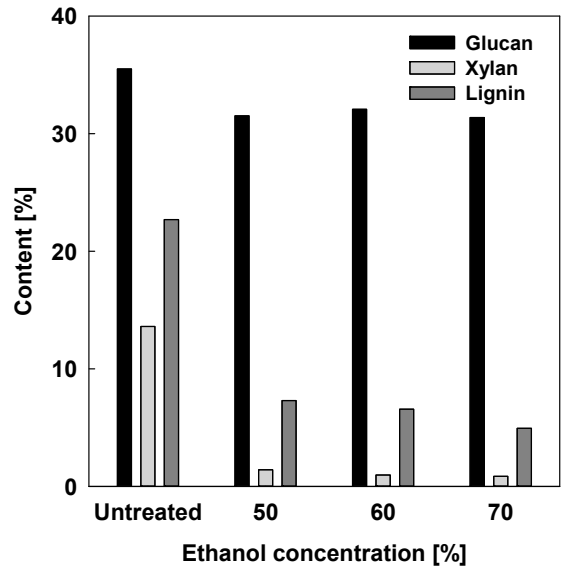

(a)

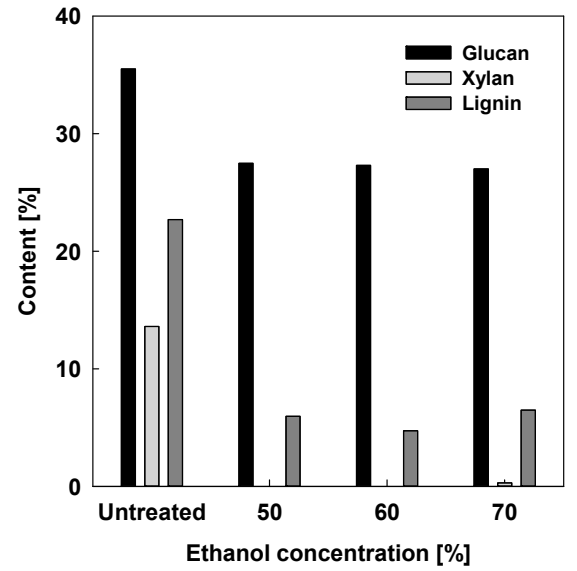

(b)

Figure 3. Effects of reaction temperature and $\mathrm{EtOH}$ concentration on the chemical compositions of raw and fractionated solid of rice husk: (a) $180{ }^{\circ} \mathrm{C}$ and (b) $190{ }^{\circ} \mathrm{C}$. Note: reaction conditions: $180-190{ }^{\circ} \mathrm{C}$, $50 \%-70 \% \mathrm{EtOH}$ concentration, $0.25 \%(w / v) \mathrm{H}_{2} \mathrm{SO}_{4}$ concentration.

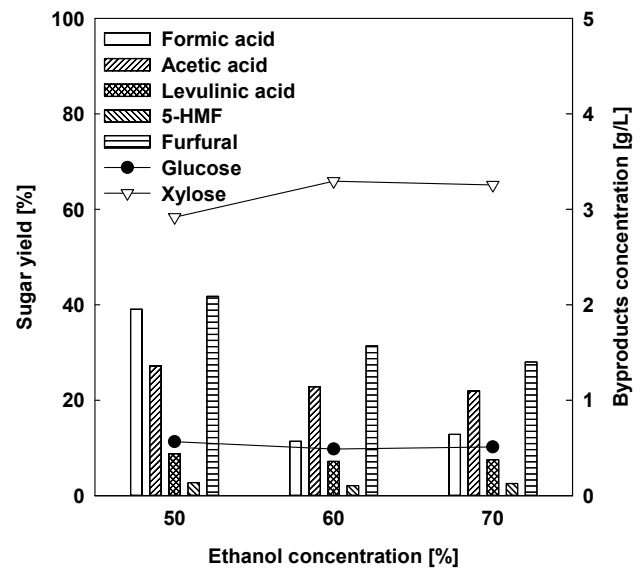

(a)

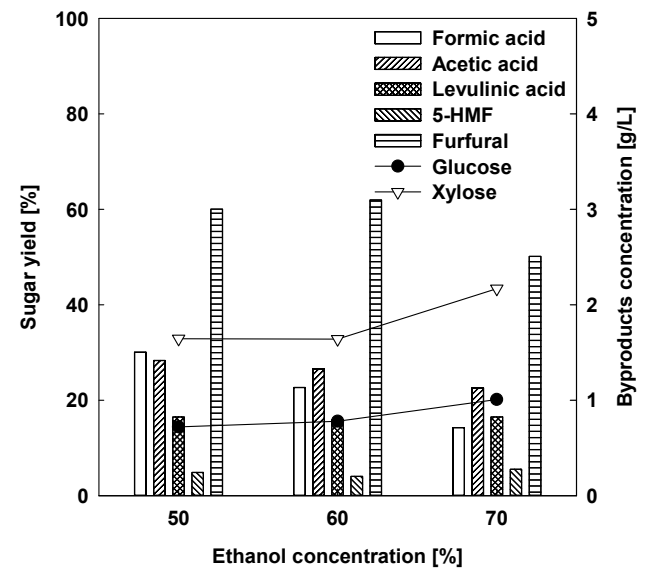

(b)

Figure 4. Effects of reaction temperature and $\mathrm{EtOH}$ concentration on the sugar extraction yield and the byproducts concentration of liquid hydrolyzate: (a) $180{ }^{\circ} \mathrm{C}$ and (b) $190{ }^{\circ} \mathrm{C}$. Note: reaction conditions: $180-190{ }^{\circ} \mathrm{C}, 50 \%-70 \%$ EtOH concentration, $0.25 \%(w / v) \mathrm{H}_{2} \mathrm{SO}_{4}$ concentration.

The delignification yield tended to increase with increasing EtOH concentration. In general, a high $\mathrm{EtOH}$ concentration increases the lignin solubility; however, $\mathrm{Ni}$ and $\mathrm{Hu}$ reported that lignin exhibited maximal solubility at an EtOH concentration of 70\% [17]. If the EtOH concentration exceeds $70 \%$, the lignin solubility decreases slightly. Therefore, the appropriate $\mathrm{EtOH}$ concentration for delignification is likely in the range from $60 \%$ to $70 \%$.

\subsubsection{Acid-Catalyzed Organosolv Fractionation for Xylose and Lignin Extraction}

The effect of acid concentration in the organosolv fractionation is shown in Figure 5. As the SA concentration was increased from $0.15 \%$ to $0.7 \%$, the glucan and xylan contents of the fractionated solid decreased (Figure 5a). At an SA concentration of 0.7\%, xylan was not present and the amount of glucan was substantially decreased. The difference in SA concentration was confirmed more clearly in the hydrolyzate results in Figure 5b. The xylose extraction yield increased with increasing SA concentration from $0.15 \%$ to $0.25 \%$. However, the highest xylose extraction yield $(67.5 \%)$ was observed at $0.25 \%$ and tended to decrease with increasing SA concentration as the SA concentration was progressively increased to $0.7 \%$. When hexose sugar (mainly glucose) is degraded under severe conditions, it is converted into formic acid, levulinic acid, and 5-HMF. A large amount of formic acid, levulinic acid, 
and 5-HMF were produced at SA concentrations of $0.35 \%$ and $0.7 \%$, accompanied by a substantial decrease of the glucan content in the fractionated RH (Figure 5b). However, the change in lignin was inconsequential as the SA concentration was increased from $0.25 \%$ to $0.7 \%$. This result means that an improvement of the delignification effect should not be expected at SA concentrations above a certain concentration. In the present system, the optimal SA concentration was determined to be $0.25 \%$.

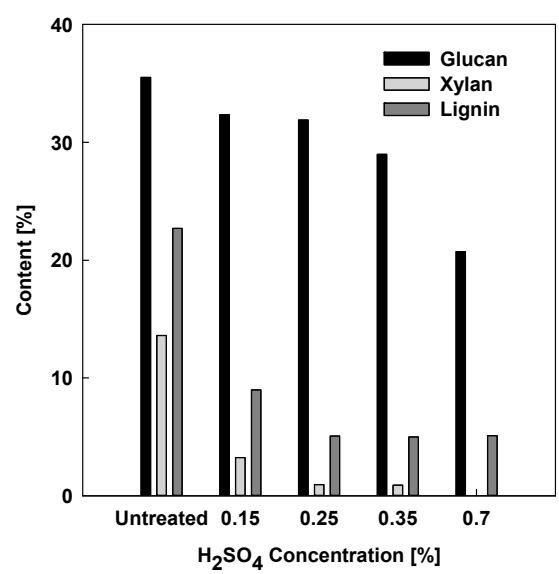

(a)

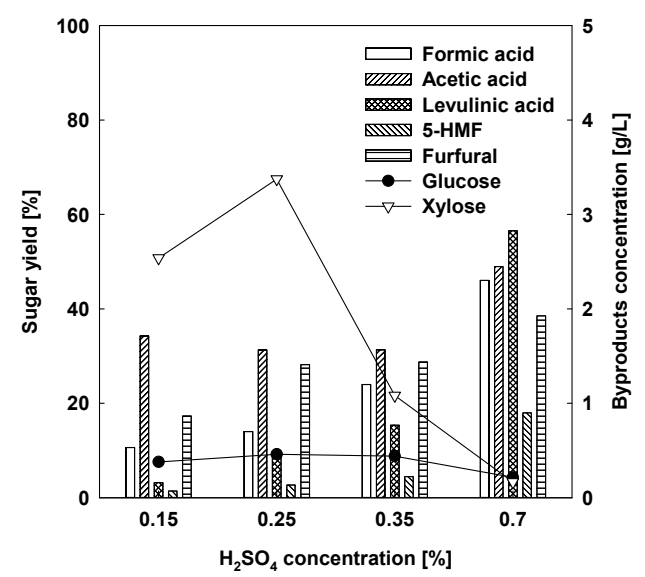

(b)

Figure 5. Effects of reaction temperature and $\mathrm{H}_{2} \mathrm{SO}_{4}$ concentration on (a) the chemical compositions of raw and fractionated solids of rice husk and $(\mathbf{b})$ the sugar extraction yield and concentration of byproducts of liquid hydrolyzate. Note: reaction conditions: $180-190{ }^{\circ} \mathrm{C}, 60 \% \mathrm{EtOH}$ concentration, $0.15 \%-0.7 \%(w / v) \mathrm{H}_{2} \mathrm{SO}_{4}$ concentration.

\subsubsection{Comparison with Acid-Free and Acid-Catalyzed Organosolv Fractionation}

The chemical compositions of raw and fractionated RH and the extraction yields of glucose and xylose (under acid-free and acid-catalyzed conditions) are compared in Figure 6. The reaction temperature, reaction time, and $\mathrm{EtOH}$ concentration were fixed at $180{ }^{\circ} \mathrm{C}, 60 \mathrm{~min}$, and $60 \%(v / v)$, respectively. As shown in Figure 6a, the glucan content did not show a dramatic difference under acid-free and acid-catalyzed conditions. By contrast, the xylose and lignin extraction yields were dramatically improved under acid catalysis. In addition, the xylose extraction yield under acid catalysis was also improved more than twofold (Figure 6b). Thus, in organosolv fractionation, SA can improve the xylose and lignin extraction yields.

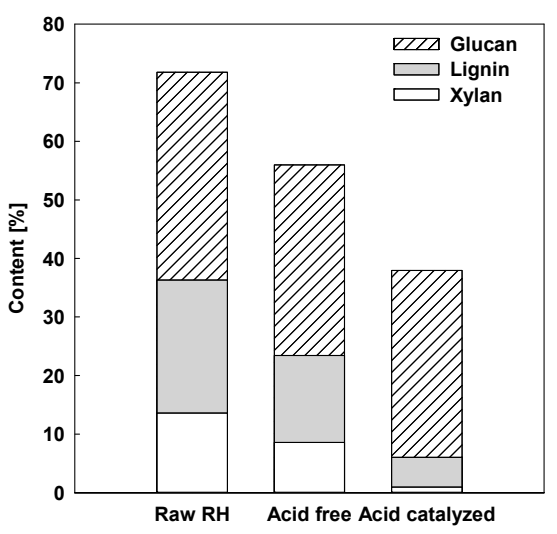

(a)

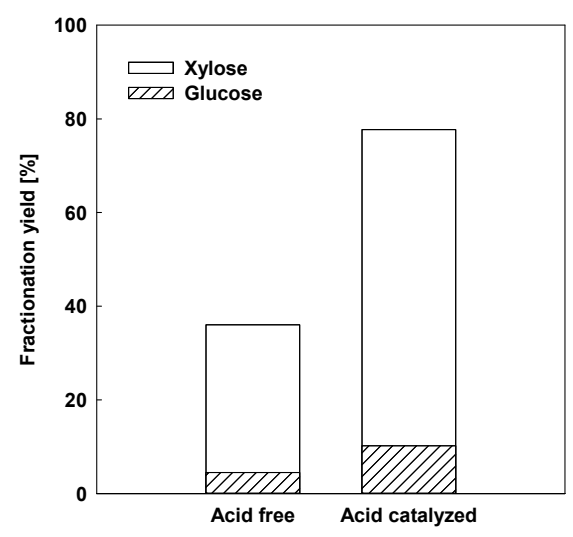

(b)

Figure 6. Comparison of acid-free and acid-catalyzed organosolv fractionations: (a) chemical composition of the fractionated $\mathrm{RH}$ and (b) the extraction yield of sugars. Note: reaction conditions: acid free: $180{ }^{\circ} \mathrm{C}, 60 \%$ EtOH concentration; acid catalyzed: $180{ }^{\circ} \mathrm{C}, 60 \%$ EtOH concentration, $0.25 \%$ $\mathrm{H}_{2} \mathrm{SO}_{4}(w / v)$ concentration. 


\subsubsection{Enzymatic Hydrolysis Tests}

The enzymatic hydrolysis tests were performed with raw and fractionated $\mathrm{RH}$; the results are present in Figure 7. The acid-catalyzed organosolv-fractionated RH showed $80.1 \%$ enzyme digestibility in $24 \mathrm{~h}$, and the maximum digestibility was $85.2 \%$ at $72 \mathrm{~h}$. By contrast, the acid-free organosolv-fractionated RH showed only $32.5 \%$ enzyme digestibility at $72 \mathrm{~h}$ and showed no appreciable difference in enzyme digestibility from the raw $\mathrm{RH}(24.5 \%)$. This lack of improvement in enzyme digestibility is attributed to xylan and phenolic compounds (lignin), which were insufficiently removed, interfering with cellulase access to the fractionated $\mathrm{RH}$.

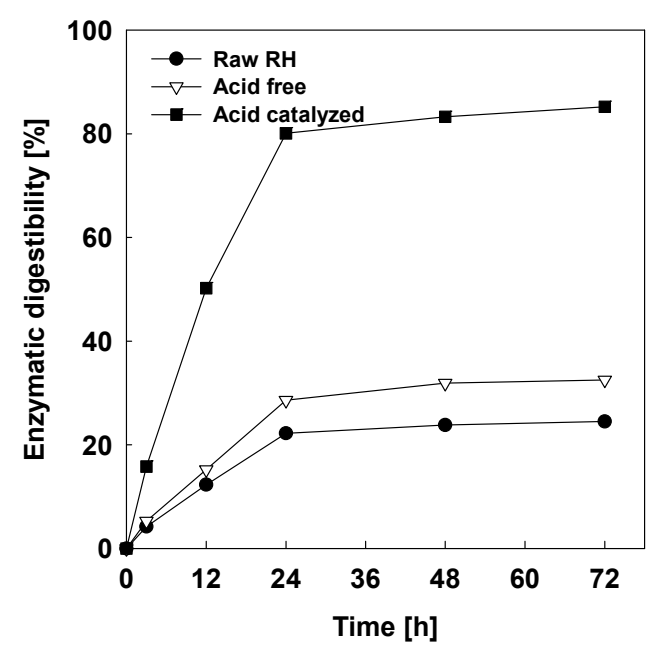

Figure 7. Enzymatic digestibility profiles of raw and fractionated $\mathrm{RH}$; acid free: $180{ }^{\circ} \mathrm{C}, 60 \% \mathrm{EtOH}$ concentration; acid catalyzed: $180{ }^{\circ} \mathrm{C}, 60 \% \mathrm{EtOH}$ concentration, $0.25 \% \mathrm{H}_{2} \mathrm{SO}_{4}(w / v)$ concentration. Note: enzymatic hydrolysis conditions: $15 \mathrm{FPU}$ of Cellic ${ }^{\circledR} \mathrm{CTec} /$ g-glucan, $\mathrm{pH} 4.8,50{ }^{\circ} \mathrm{C}$, and $150 \mathrm{rpm}$.

\subsection{Chemical Characteristics of Organosolv-Fractionated Lignin}

The hydroxyl groups, which include aliphatic hydroxyl groups, phenolic hydroxyl groups ( $p$-hydroxyphenyl units, guaiacyl units, and syringyl units), and carboxyl groups of lignin, were analyzed by ${ }^{31} \mathrm{P}$ NMR. The amounts of hydroxyl groups were calculated on the basis of an internal standard (cyclohexanol); the respective integrated peak areas are presented in Table 1 . The $M_{n}, M_{\mathrm{w}}$, and PD of lignin were determined by GPC; the results are presented in Table 1. As shown in Table 1, the acid-catalyzed organosolv-fractionated lignin contained higher concentrations of phenolic hydroxyl groups and carboxyl groups compared with the acid-free organosolv-fractionated lignin. This result is related to the severity of the reaction. In general, the $\beta$-aryl ether linkage is known to occupy $50 \%$ of the lignin structure [18]. With increasing reaction severity, phenolic hydroxyl and carboxyl groups generate more aromatic monomers through cleavage of the $\beta$-O-4 linkage [19]. Furthermore, cleaving $\beta$-O-4 linkages causes a decrease in lignin molecular weight [20]. These results are consistent with the molecular-weight results shown in Table 1, where the molecular weight of acid-catalyzed organosolv-fractionated lignin was higher than that of acid-free organosolv-fractionated lignin 
Table 1. Hydroxyl groups and molecular weight of acid-free and acid-catalyzed organosolv precipitated lignin from RH.

\begin{tabular}{ccccc}
\hline Content & Classify & Unit & Acid-Free & Acid Catalyzed \\
\hline \multirow{4}{*}{ Hydroxyl group } & Aliphatic unit & $\mathrm{mmol} / \mathrm{g}$ & 2.84 & 2.76 \\
& p-Hydroxyphenyl unit & $\mathrm{mmol} / \mathrm{g}$ & 0.49 & 0.50 \\
& Guaiacyl unit & $\mathrm{mmol} / \mathrm{g}$ & 1.19 & 1.62 \\
& Syringyl unit & $\mathrm{mmol} / \mathrm{g}$ & 0.54 & 0.56 \\
& Phenols unit & $\mathrm{mmol} / \mathrm{g}$ & 2.21 & 2.68 \\
& Carbonyl unit & $\mathrm{mmol} / \mathrm{g}$ & 0.04 & 0.09 \\
\hline \multirow{3}{*}{ Molecular weight } & $M_{\mathrm{n}}{ }^{1}$ & $\mathrm{~g} / \mathrm{mol}$ & 1296 & 1073 \\
& $M_{\mathrm{w}}{ }^{2}$ & $\mathrm{~g} / \mathrm{mol}$ & 1627 & 1422 \\
& $\mathrm{PDI}^{3}$ & - & 1.26 & 1.33 \\
\hline
\end{tabular}

${ }^{1}$ Number-average molecular weight, ${ }^{2}$ Weight-average molecular weight, ${ }^{3}$ Polydispersity index $\left(M_{w} / M_{n}\right)$.

The previously presented results indicate that the acid-catalyzed organosolv-fractionated lignin has a low molecular weight, uniform molecular weight distribution, and a high concentration of phenolic hydroxyl groups. The phenolic hydroxyl groups increase the reactivity of lignin toward formaldehyde when aromatic polymers are used in phenolic resin formulations [21,22]. Therefore, lignin with these characteristics would be suitable for application in the biorefinery field.

\subsection{Overall Fractionation Yield and Total Mass Balance}

The extraction mass balance (EMB) of raw and fractionated RH was present in Table 2. In the acid-free organosolv fractionation, $91.8 \%$ of glucan was preserved from the fractionated $\mathrm{RH}$ and $31.6 \%$ of xylose and $11.0 \%$ of lignin were obtained from the liquid hydrolyzate. By contrast, in the acid-catalyzed organosolv fractionation, $89.9 \%$ of glucan was preserved from the fractionated $\mathrm{RH}$ and $67.6 \%$ of xylose and $49.8 \%$ of lignin were obtained from the liquid hydrolyzate. As the P lignin shown in Table 2 was lignin precipitated from liquid hydrolyzate, conclusively, three main components (glucan, xylose, and lignin) of RH were separated. Therefore, the acid-catalyzed organosolv pretreatment is a valuable process to fractionate three main components for $\mathrm{RH}$ in the biorefinery field.

Table 2. Extraction mass balance of sugars and lignin with acid-free acid acid catalyzed orgarnosolv fractionation of $\mathrm{RH}$.

\begin{tabular}{|c|c|c|c|c|c|c|c|c|c|c|c|}
\hline \multirow{2}{*}{\multicolumn{2}{|c|}{ Sample }} & \multirow{2}{*}{ S.R. [\%] } & \multicolumn{3}{|c|}{ Solid [\%] } & \multicolumn{3}{|c|}{ Liquid [\%] } & \multicolumn{3}{|c|}{ EMB $^{1}[\%]$} \\
\hline & & & Glucan & Xylan & Lignin & Glucose & Xylose & P. Lignin ${ }^{2}$ & Glucan & Xylan & Lignin \\
\hline \multicolumn{2}{|c|}{ Raw RH } & 100 & 35.5 & 13.6 & 22.7 & - & - & - & - & - & - \\
\hline \multirow{2}{*}{ Acid-Free } & Fractionated & \multirow{2}{*}{71.7} & 46.9 & 12.0 & 20.8 & \multirow{2}{*}{1.6} & \multirow{2}{*}{4.3} & \multirow{2}{*}{2.5} & \multirow{2}{*}{99.2} & \multirow{2}{*}{94.7} & \multirow{2}{*}{76.7} \\
\hline & Fractionated $^{3}$ & & 32.6 & 8.6 & 14.9 & & & & & & \\
\hline \multicolumn{3}{|c|}{ Component Retention [\%] } & 91.8 & 63.7 & 65.6 & - & - & - & - & - & - \\
\hline \multirow{2}{*}{$\begin{array}{c}\text { Acid } \\
\text { Catalyzed }\end{array}$} & Fractionated & \multirow{2}{*}{50.9} & 62.7 & 2.0 & 10.0 & \multirow{2}{*}{3.3} & \multirow{2}{*}{9.2} & \multirow{2}{*}{11.3} & \multirow{2}{*}{99.2} & \multirow{2}{*}{75.6} & \multirow{2}{*}{72.2} \\
\hline & Fractionated $^{3}$ & & 31.9 & 1.0 & 5.1 & & & & & & \\
\hline \multicolumn{3}{|c|}{ Component Retention [\%] } & 89.9 & 7.4 & 22.5 & - & - & - & - & - & \\
\hline \multicolumn{12}{|c|}{$\begin{array}{l}\text { Fractionation conditions: Acid-free: } 180{ }^{\circ} \mathrm{C}, 60 \mathrm{~min}, 60 \%(v / v) \mathrm{EtOH} \text {; acid catalyzed: } 180{ }^{\circ} \mathrm{C}, 60 \mathrm{~min}, 60 \%(v / v) \\
\text { EtOH, } 0.25 \%(w / v) \mathrm{H}_{2} \mathrm{SO}_{4} \cdot{ }^{1} \text { Extraction mass balance }(\mathrm{EMB})=\left(\sum \mathrm{C}_{L i}+\sum C_{S i}\right) /\left(\sum \mathrm{C}_{R i}\right) \text {, where } C_{i} \text { is the mass of each } \\
\text { component as } C_{L i} \text {, as determined through } \mathrm{HPLC} \text { chromatography. The subscripts } L, S \text {, and } R \text { refer to the extracted } \\
\text { liquid, fractionated solids, and raw fractions respectively. }{ }^{2} \text { Precipitated lignin from liquid hydrolyzate. }{ }^{3} \text { Data are } \\
\text { based on the oven-dried raw biomass. }\end{array}$} \\
\hline
\end{tabular}

The simplified flowchart and an overall mass balance of the acid-catalyzed organosolv fractionation and consecutive enzymatic hydrolysis are summarized in Figure 8. Most of the hemicellulose and lignin were separated from the RH by organosolv fractionation with SA. Under the optimized conditions, approximately $49.9 \mathrm{~g}$ of the mass fraction was solubilized into liquid hydrolysate, which involved discharging $11.8 \mathrm{~g}$ of xylan, $17.6 \mathrm{~g}$ of lignin, and $4.7 \mathrm{~g}$ of glucan (based on $100 \mathrm{~g}$ of raw $\mathrm{RH}$ ) from the 
reactor for recovery of lignin by the precipitation method. The residual solid, i.e., $50.1 \mathrm{~g}$ of acid-catalyzed fractionated $\mathrm{RH}$, was subjected to consecutive enzymatic hydrolysis. The liquor resulting from the enzymatic hydrolysis had a sugar fraction including $30.0 \mathrm{~g}$ of glucose and $1.5 \mathrm{~g}$ of xylose, which could be easily used for microbial fermentation. The acid-catalyzed organosolv fractionation was assumed to have greatly increased the cellulase effectiveness through the removal of hemicellulose and lignin.

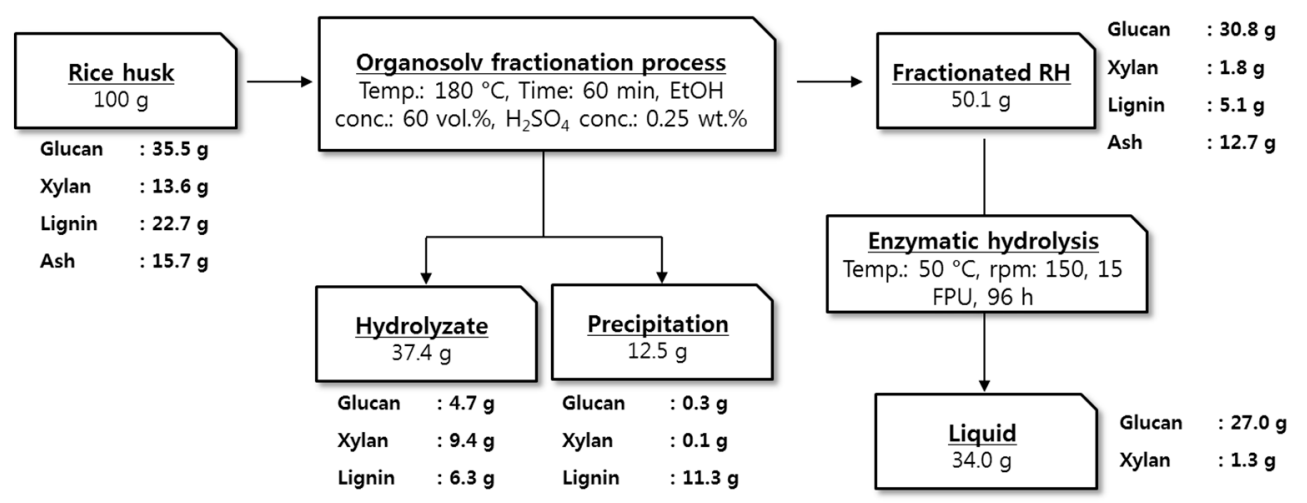

Figure 8. Overall mass balance of the organosolv fractionation process of RH under optimal conditions.

\section{Materials and Methods}

\subsection{Materials}

RH was harvested at Gimpo-si, Gyeonggi-do, Korea and collected in 2017. The RH was ground with a blend mill (Blender 7012s, Waring Commercial, Stamford, CT, USA) and then sieved to a nominal size of 14-45 mesh (from 0.36 to $1.4 \mathrm{~mm}$ ). The ground $\mathrm{RH}$ was placed in a convection oven at $45 \pm$ $5{ }^{\circ} \mathrm{C}$ for $48 \mathrm{~h}$ and then stored in an automatic dehumidification desiccator until used. The average moisture content of the dried RH was $4.3 \%$ during the experiment. The composition of the RH was determined by the National Renewable Energy Laboratory (NREL, Golden, CO, USA) Laboratory Standard Procedure (LAP) [23-28]. The chemical composition of the raw RH was $35.6 \%$ glucan, $13.6 \%$ xylan, $1.7 \%$ arabinan, $22.7 \%$ acid insoluble lignin (AIL), $0.7 \%$ acid-soluble lignin (ASL), $1.2 \% \mathrm{EtOH}$ extractives, $6.6 \%$ water extractives, and $15.7 \%$ ash $(n=3$, standard deviations $<0.8)$.

EtOH (cat. no. E7023), sodium azide (cat. no. S2002), tetrahydrofuran (THF, cat. no. 401757), pyridine (cat. no. 270970), chloroform-d (cat. no. 151858), cyclohexanol (cat. no. 105899), chromium(III) acetylacetonate (cat. no. 574082), 2-chloro-4,4,5,5-tetramethyl-1,2,3-dioxaphospholane (TMDP, cat. no. 447536), and cellulase enzyme Cellic ${ }^{\circledR}$ CTec2 (Novozymes, A/S Bagsvaerd, Denmark) were purchased from Sigma-Aldrich Korea.

\subsection{Experimental Setup and Operation}

The batch reactor used for the organosolv fractionation process consisted of reaction baths (a molten salt bath and a silicone oil bath) and a cooling bath (water bath). The temperatures of the molten salt bath and the silicone oil bath could be driven to $250{ }^{\circ} \mathrm{C}$ and $200{ }^{\circ} \mathrm{C}$, respectively. The molten salt bath was used for preheating to the target temperature, the silicone oil bath was used for maintaining the reaction temperature, and the water bath was used for cooling. The average preheating time was less than $1.0 \mathrm{~min}$ under all of the investigated reaction temperature conditions. The fractionation reactor, a bomb tubular reactor, was constructed of SS-316L tubing with a $10.9 \mathrm{~mm}$ ID and a $150 \mathrm{~mm}$ length $\left(14.0 \mathrm{~cm}^{3}\right.$ internal volume). The temperatures of the reaction baths and fractionation reactors were measured continuously with high-temperature thermocouples (catalog number HY-72D, Hanyoung Nux, Incheon, Korea). The timer and movement controller were set up to control the reaction time and movement of the fractionation reactors, respectively. 
When the reaction was completed, the liquid samples were removed from the reactor, diluted threefold with deionized (DI) water to precipitate the lignin, and then evaporated in a drying oven at $55^{\circ} \mathrm{C}$ for $4 \mathrm{~h}$. The liquid samples were analyzed to determine their concentrations of carbohydrates (i.e., glucose, xylose, and arabinose) and byproducts. The fractionated solids discharged from the reactor were separated into two portions. One portion was dried using a convection oven for weight-loss measurement and composition analysis. The other portion was subjected to an enzymatic digestibility test in the wet state.

\subsection{Enzymatic Digestibility Tests}

The enzymatic digestibility test of raw and fractionated $\mathrm{RH}$ was determined according to the NREL LAP [27]. The tests were conducted under the following conditions: $50{ }^{\circ} \mathrm{C}, \mathrm{pH} 4.8(0.05 \mathrm{M}$ sodium citrate buffer), $150 \mathrm{rpm}$ in a shaking incubator (model VS-8480SFN, Vision Scientific Co., Bucheon, Korea) and 15 FPU g-glucan enzyme loadings. The average activity of the cellulase was measured to be $119.4 \mathrm{FPU} / \mathrm{mL}$. The initial glucan concentration was $1.0 \%(w / v)$ based on $100 \mathrm{~mL}$ of total liquid in a $250 \mathrm{~mL}$ Erlenmeyer flask. To prevent microbial contamination, $1.0 \mathrm{~mL}$ of $20 \mathrm{mg} / \mathrm{mL}$ sodium azide was added. Samples were collected periodically at appropriate sampling times $(6,12,24$, 48 , and $72 \mathrm{~h}$ ) and analyzed for hydrolyzed glucose using a high-performance liquid chromatography (HPLC) system.

\subsection{Composition Analysis of Raw and Fractionated $R H$}

The chemical compositions of the solid and liquid samples were determined according to the procedures of the NREL-LAP $[24,25,28]$. The extractives process was carried out in two steps using water and EtOH consecutively. For the composition analysis of extractives-free and fractionated solids, two-step acid hydrolysis was carried out.

An HPLC system (LC-10A, Shimadzu Inc., Kyoto, Japan) with a refractive index (RI) detector (RID-10A, Shimadzu Inc., Kyoto, Japan) was used to determine the carbohydrate and organic acid components of the samples. For analysis of monomeric sugars from the raw and fractionated $\mathrm{RH}$ samples, a carbohydrate column (Aminex HPX-87P, Bio-Rad Inc., Hercules, CA, USA) was used; HPLC-grade water was used as the mobile phase with a volumetric flow rate of $0.4 \mathrm{~mL} / \mathrm{min}$. The samples were neutralized with calcium carbonate and filtered $(0.2 \mu \mathrm{m}$ pore size) before analysis. The operating temperature of the column was $80^{\circ} \mathrm{C}$. The liquid hydrolysis samples and enzymatic hydrolysis samples were analyzed using an organic acid column (Aminex HPX-87H, Bio-Rad Inc., Hercules, CA, USA); $5 \mathrm{mM} \mathrm{SA}$ was used as a mobile phase with a volumetric flow rate of $0.5 \mathrm{~mL} / \mathrm{min}$. These samples were also neutralized with calcium carbonate and filtered $(0.4 \mu \mathrm{m}$ pore size $)$ before analysis. The operating temperature of the column was $65^{\circ} \mathrm{C}$.

\subsection{Chemical Characterization of Organosolv Fractionated Lignin}

The number-average molar mass $\left(M_{\mathrm{n}}\right)$, weight-average molar mass $\left(M_{\mathrm{w}}\right)$, and polydispersity (PD) of the organosolv fractionated lignin samples were determined by gel permeation chromatography (GPC, Ultimate 3000, Thermo Fisher Scientific Inc., Waltham, MA, USA). For molecular-weight determination, $3 \mathrm{mg}$ of an acetylated lignin sample was dissolved in $2 \mathrm{~mL}$ of THF and filtered with a $0.45 \mu \mathrm{m}$ polytetrafluoroethylene (PTFE) syringe filter to remove impurities. The GPC system was equipped with a Shodex column (KF-806L with Shodex KF-G guard column, Showa Denko, Tokyo, Japan) and an RI detector (Refracto Max 520, Thermofisher Scientific Korea Ltd, Seoul, Korea); THF was used as the mobile phase $(1.0 \mathrm{~mL} / \mathrm{min})$; the injection volume was $20 \mu \mathrm{L}$.

${ }^{31} \mathrm{P}$ NMR (Avance 600, Bruker, Billerica, MA, USA) spectra were recorded at $242.88 \mathrm{MHz}$ and 256 scans with a $2 \mathrm{~s}$ pulse delay. For quantitative ${ }^{31} \mathrm{P}$ NMR analysis, $20 \mathrm{mg}$ of lignin sample was accurately weighed and dissolved in $400 \mu \mathrm{L}$ of solution $\mathrm{A}$ and $150 \mu \mathrm{L}$ of solution B in a $5 \mathrm{~mL}$ vial. Solution A was a mixture of pyridine and chloroform-d $\left(\mathrm{CDCl}_{3}\right)$ at a ratio of 1.6:1 $(\mathrm{v} / \mathrm{v})$. Solution $\mathrm{B}$ was a mixture of solution A (25 mL), cyclohexanol (100 mg), and chromium(III) acetylacetonate (90 mg). The dissolved 
liquid was vortexed for $5 \mathrm{~min}, 70 \mu \mathrm{L}$ of TMDP was added to the solution, and the resultant mixture was analyzed with the ${ }^{31} \mathrm{P}$ NMR system.

Fourier transform infrared (FTIR) spectroscopy (IRSpirit-L/T, Shimadzu Inc., Kyoto, Japan) was used to determine the characteristic absorption peaks of the chemical functional groups in the organosolv-fractionated lignin via the attenuated total reflectance (ATR) technique. Mid-IR spectra were collected by averaging 40 scans collected at a resolution of $1 \mathrm{~cm}^{-1}$ over the wavenumber region from 4000 to $500 \mathrm{~cm}^{-1}$.

\section{Conclusions}

The results of this work indicate that acid-catalyzed organosolv fractionation using a low reaction severity (i.e., low acid concentration) is a worthwhile process in the field of biorefinery. Very pure lignin fractions were recovered, and the resulting hydrolyzate, xylose-rich liquid fraction can potentially be used for xylose-uptaking fermentations; similarly, the insoluble residue, the cellulose-rich solid fraction, could potentially be readily hydrolyzed at a low enzyme loading into glucose. These findings strongly suggest that a biorefinery procedure is required prior to a five-carbon fermentation process, as well as catalytic conversion of fractionated lignin, for full valorization of the cellulosic biomass.

Author Contributions: T.H.K., H.J.R., and K.K.O. contributed equally to this work. T.H.K. contributed to the experimental process for RH Fractionation and T.H.K. contributed to the project administration and experimental design. And H.J.R. contributed to providing the methodology and data validation. All of the authors contributed to the writing and review of this document.

Funding: This work was supported by the R and D program of Korea Institute of Energy Technology Evaluation and Planning (KETEP) grant funded by the Ministry of Trade, Industry and Energy (MOTIE), the Republic of Korea (No. 20183030091950).

Conflicts of Interest: The authors declare no conflict of interest.

\section{References}

1. Lim, J.S.; Manan, Z.A.; Alwi, S.R.W.; Hashim, H. A review on utilisation of biomass from rice industry as a source of renewable energy. Renew. Sustain. Energy Rev. 2012, 16, 3084-3094. [CrossRef]

2. Zhang, H.; Ding, X.; Chen, X.; Ma, Y.; Wang, Z.; Zhao, X. A new method of utilizing rice husk: Consecutively preparing d-xylose, organosolv lignin, ethanol and amorphous superfine silica. J. Hazard. Mater. 2015, 291, 65-73. [CrossRef]

3. Soltani, N.; Bahrami, A.; Pech-Canul, M.I.; González, L.A. Review on the physicochemical treatments of rice husk for production of advanced materials. Chem. Eng. J. 2015, 264, 899-935. [CrossRef]

4. Menya, E.; Olupot, P.W.; Storz, H.; Lubwama, M.; Kiros, Y. Production and performance of activated carbon from rice husks for removal of natural organic matter from water: A review. Chem. Eng. Res. Des. 2018, 129, 271-296. [CrossRef]

5. Kim, T.H.; Kim, T.H. Consecutive Recovery of Non-Structural Sugars and Xylooligomers from Corn Stover using Hot Water and Acidified Calcium Chloride. BioResources 2018, 13, 7294-7309. [CrossRef]

6. International Energy Agency. Available online: https://www.ieabioenergy.com/publications/bio-basedchemicals-value-added-products-from-biorefineries/ (accessed on 14 March 2019).

7. Chen, H.; Liu, J.; Chang, X.; Chen, D.; Xue, Y.; Liu, P.; Lin, H.; Han, S. A review on the pretreatment of lignocellulose for high-value chemicals. Fuel Process. Technol. 2017, 160, 196-206. [CrossRef]

8. Guo, Y.; Zhou, J.; Wen, J.; Sun, G.; Sun, Y. Structural transformations of triploid of Populus tomentosa Carr. lignin during auto-catalyzed ethanol organosolv pretreatment. Ind. Crops Prod. 2015, 76, 522-529. [CrossRef]

9. Zhao, X.; Cheng, K.; Liu, D. Organosolv pretreatment of lignocellulosic biomass for enzymatic hydrolysis. Appl. Microbiol. Biotechnol. 2009, 82, 815. [CrossRef] [PubMed]

10. Zhang, K.; Pei, Z.; Wang, D. Organic solvent pretreatment of lignocellulosic biomass for biofuels and biochemicals: A review. Bioresour. Technol. 2016, 199, 21-33. [CrossRef]

11. Lora, J.H.; Glasser, W.G. Recent industrial applications of lignin: A sustainable alternative to nonrenewable materials. J. Polym. Environ. 2002, 10, 39-48. [CrossRef] 
12. Teramoto, Y.; Tanaka, N.; Lee, S.H.; Endo, T. Pretreatment of eucalyptus wood chips for enzymatic saccharification using combined sulfuric acid-free ethanol cooking and ball milling. Biotechnol. Bioeng. 2008, 99, 75-85. [CrossRef] [PubMed]

13. Kim, T.H.; Im, D.J.; Oh, K.K. Effects of Organosolv Pretreatment Using Temperature-Controlled Bench-Scale Ball Milling on Enzymatic Saccharification of Miscanthus $\times$ giganteus. Energies 2018, 11, 2657. [CrossRef]

14. Pan, X.; Kadla, J.F.; Ehara, K.; Gilkes, N.; Saddler, J.N. Organosolv ethanol lignin from hybrid poplar as a radical scavenger: Relationship between lignin structure, extraction conditions, and antioxidant activity. J. Agric. Food Chem. 2006, 54, 5806-5813. [CrossRef] [PubMed]

15. Weinwurm, F.; Turk, T.; Denner, J.; Whitmore, K.; Friedl, A. Combined liquid hot water and ethanol organosolv treatment of wheat straw for extraction and reaction modeling. J. Clean. Prod. 2017, 165, 1473-1484. [CrossRef]

16. Kim, T.H.; Jeon, Y.J.; Oh, K.K.; Kim, T.H. Production of furfural and cellulose from barley straw using acidified zinc chloride. Korean J. Chem. Eng. 2013, 30, 1339-1346. [CrossRef]

17. Pan, X.; Gilkes, N.; Kadla, J.; Pye, K.; Saka, S.; Gregg, D.; Ehara, K.; Xie, D.; Lam, D.; Saddler, J. Bioconversion of hybrid poplar to ethanol and co-products using an organosolv fractionation process: Optimization of process yields. Biotechnol. Bioeng. 2006, 94, 851-861. [CrossRef]

18. Agarwal, A.; Rana, M.; Park, J.H. Advancement in technologies for the depolymerization of lignin. Fuel Process. Technol. 2018, 181, 115-132. [CrossRef]

19. Yáñez-S, M.; Matsuhiro, B.; Nunez, C.; Pan, S.; Hubbell, C.A.; Sannigrahi, P.; Ragauskas, A.J. Physicochemical characterization of ethanol organosolv lignin (EOL) from Eucalyptus globulus: Effect of extraction conditions on the molecular structure. Polym. Degrad. Stab. 2014, 110, 184-194. [CrossRef]

20. Domínguez-Robles, J.; Tamminen, T.; Liitiä, T.; Peresin, M.S.; Rodríguez, A.; Jääskeläinen, A.S. Aqueous acetone fractionation of kraft, organosolv and soda lignins. Int. J. Biol. Macromol. 2018, 106, 979-987. [CrossRef]

21. El Mansouri, N.E.; Salvadó, J. Structural characterization of technical lignins for the production of adhesives: Application to lignosulfonate, kraft, soda-anthraquinone, organosolv and ethanol process lignins. Ind. Crops Prod. 2006, 24, 8-16. [CrossRef]

22. Fahmi, R.; Bridgwater, A.V.; Donnison, I.; Yates, N.; Jones, J.M. The effect of lignin and inorganic species in biomass on pyrolysis oil yields, quality and stability. Fuel 2008, 87, 1230-1240. [CrossRef]

23. Hames, B.; Ruiz, R.; Scarlata, C.; Sluiter, A.; Sluiter, J.; Tmpleton, D. Preparation of Samples for Compositional Analysis; NREL/TP-510-42620; National Renewable Energy Laboratory: Golden, CO, USA, 2012.

24. Sluiter, A.; Ruiz, R.; Scarlata, C.; Sluiter, J.; Templeton, D. Determination of Extractives in Biomass; NREL/TP-510-42619; National Renewable Energy Laboratory: Golden, CO, USA, 2012.

25. Sluiter, A.; Hames, B.; Ruiz, R.; Scarlata, C.; Sluiter, J.; Templeton, D. Determination of Structural Carbohydrates and Lignin in Biomass; NREL/TP-510-42618; National Renewable Energy Laboratory: Golden, CO, USA, 2012.

26. Sluiter, A.; Hames, B.; Ruiz, R.; Scarlata, C.; Sluiter, J.; Templeton, D. Determination of Ash in Biomass; NREL/TP-510-42622; National Renewable Energy Laboratory: Golden, CO, USA, 2008.

27. Sluiter, A.; Hames, B.; Ruiz, R.; Scarlata, C.; Sluiter, J.; Templeton, D. Determination of Sugars, Byproducts, and Degradation Products in Liquid Fraction Process Samples; NREL/TP-510-42623; National Renewable Energy Laboratory: Golden, CO, USA, 2008.

28. Selig, M.; Weiss, N.; Ji, Y. Enzymatic Saccharification of Lignocellulosic Biomass; NREL/TP-510-42629; National Renewable Energy Laboratory: Golden, CO, USA, 2008.

(C) 2019 by the authors. Licensee MDPI, Basel, Switzerland. This article is an open access article distributed under the terms and conditions of the Creative Commons Attribution (CC BY) license (http://creativecommons.org/licenses/by/4.0/). 